\title{
Brexit a wybory do Parlamentu Europejskiego w 2019 roku. Rozważania na tle wyborów w Polsce
}

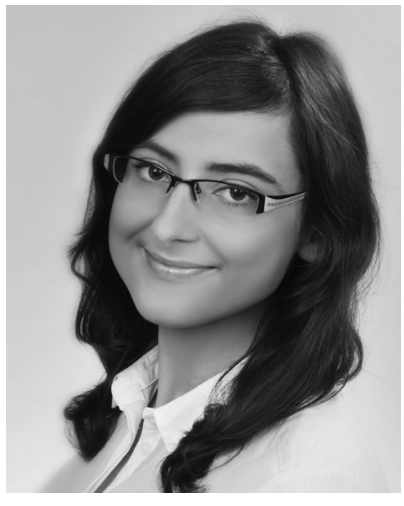

\section{Agata Pyrzyńska}

Doktor nauk prawnych, adiunkt w Instytucie Nauk Prawnych Uniwersytetu Szczecińskiego; zainteresowania naukowe koncentruje na zagadnieniach prawa konstytucyjnego i wyborczego.

$\triangle$ agata.pyrzynska@usz.edu.pl https://orcid.org/oooo-0002-4573-4310

\section{Brexit and the European Parliament Elections in 2019. Considerations in the Context of the Elections in Poland}

\begin{abstract}
The withdrawal of Great Britain from the European Union turned out to be important not only for the citizens of this country but for all Member States of the European Union. One of the important consequences of the notification of the withdrawal from the organization was to determine the constitution of the European Parliament taking into account variants of the moment when Brexit takes effect. The paper analyzes the impact of the UK's withdrawal from the European Union on the conduct of elections and the appointment of seats in the European Parliament. This issue is presented primarily on the example of the elections held in Poland. The first part of the article discusses the procedure for the withdrawal of Great Britain from the EU and related problems. The second part is devoted to the impact of Brexit on the distribution of seats in the EP depending on the moment of Great Britain's withdrawal from the European Union. The third part of the article examines problems associated with the procedure for indicating a Polish representative awaiting his mandate and his status.
\end{abstract}

Słowa kluczowe: wybory, Parlament Europejski, poset, brexit, prawo wyborcze

Key words: elections, European Parliament, deputy, Brexit, electoral law https://doi.org/10.32082/fp.v0i4(60).365

\section{Wprowadzenie}

Powstanie i kształtowanie się Wspólnot, a następnie Unii Europejskiej jako organizacji międzynarodowej integrującej państwa europejskie na wielu płaszczyznach, bez wątpienia uznać należy za jeden $z$ najważniejszych proce- sów zachodzących w powojennej Europie. Unia stała się organizacją unikatową, w której państwa o zróżnicowanych wartościach, tradycjach i kulturze ${ }^{1}$ podjęły

1 Nie bez znaczenia jest dewiza Unii Europejskiej „Zjednoczeni w róż- 
próbę budowania względnie trwałego pomostu pomiędzy narodami Europy, przyjmując jednocześnie zobowiązanie do przestrzegania wspólnych norm prawa unijnego. Jak jednak pokazała praktyka, ponadnarodowa współpraca i ważenie interesów nie zawsze są zadaniem prostym, a samo członkostwo w Unii bezwzględnie trwałe. Przykład Wielkiej Brytanii pokazał bowiem, że nawet ponad czterdziestoletnie wspólne doświadczenia w budowaniu zjednoczonej Europy nie są gwarancją wypracowania jednolitych stanowisk na wszystkich polach integracji. premiera Davida Camerona ${ }^{3}$. Uprawnieni do udziału w referendum mieli możliwość wyrażenia w nim opinii w przedmiocie dalszej integracji bądź zerwania opartej na unijnych zasadach współpracy. W referendum tym aż 51,9\% głosujących opowiedziało się za opuszczeniem przez Wielką Brytanię Unii Europejskiej ${ }^{4}$, co otworzyło drogę do uruchomienia procedury określonej w art. 50 TUE. Przywołany przepis, wprowadzony do unijnego porządku prawnego przez Traktat z Lizbony ${ }^{5}$, przewiduje jedyną prawną możliwość wystąpienia z UE6. Na mocy ust. 1 tego artykułu

\section{Jednym z ważniejszych wyzwań, z którymi przyszło zmierzyć się Unii Europejskiej, jest bez wątpienia brexit.}

Jednym z ważniejszych wyzwań, z którymi przyszło zmierzyć się Unii Europejskiej, jest bez wątpienia brexit. Choć pojęcie to nie należy do języka prawnego, na trwałe wpisało się w europejski dyskurs polityczny, a co za tym idzie - jest powszechnie stosowane, $w$ tym także wśród wysokich urzędników unijnych. Pod pojęciem tym rozumieć należy bezprecedensową dotychczas procedurę wystąpienia państwa członkowskiego z Unii Europejskiej, a mianowicie proces opuszczenia organizacji przez Wielką Brytanię ${ }^{2}$. Warto jednak odnotować, że w literaturze pojęcie to łączone jest niekiedy także z wydarzeniem, które bezpośrednio poprzedziło podjęcie formalnych środków do osiągnięcia tego celu. Mowa tu o referendum przeprowadzonym 23 czerwca 2016 r. w Wielkiej Brytanii z inicjatywy ówczesnego jej

norodności”, której brzmienie z jednej strony podkreśla bogactwo tradycji, kultur, języków państw członkowskich UE, z drugiej zaś wskazuje na zasadnicze cele określone w art. 3 Traktatu o Unii Europejskiej (wersja skonsolidowana Dz.Urz. UE C 202 z 7.6.2016, s. 13-46) dalej jako TUE.

2 Ciekawie na temat zasadniczych osi debaty nad wystąpieniem Wielkiej Brytanii z UE pisał m.in. M.P. Garapich, Brexit-fakty, mity, liczby. Możliwe konsekwencje wystąpienia Wielkiej Brytanii z Unii Europejskiej. Analiza głównych osi debat publicznych, Warszawa 2016, s. 9 i n. każde państwo członkowskie może, zgodnie ze swoimi wymogami konstytucyjnymi, podjąć decyzję o wystąpieniu z Unii. W myśl art. 50 ust. 2 TUE obowiązkiem państwa, które podjęło decyzję o wystąpieniu, jest notyfikacja tego faktu Radzie Europejskiej, w dalszej

3 T.R. Szymczyński, Brexit a wyzwania identyfikacyjne w odniesieniu do procesu integracji europejskiej z perspektywy hermeneutycznej, „Rocznik Integracji Europejskiej” 2016, nr 10, s. 68-69; K. Kupis, Swój - obcy - inny. Brexit i jego społeczne konsekwencje, „Polonia Journal” 2017, nr 5-6, s. 78.

4 Warto odnotować, że w referendum udział wzięło $72,2 \%$ uprawnionych; por. Results and turnout at the EU referendum, The Electoral Commission (UK), https://www. electoralcommission.org.uk/who-we-are-and-what-we-do/ elections-and-referendums/past-elections-and-referendums/ eu-referendum/results-and-turnout-eu-referendum (dostęp 09.02.2020)

5 Traktat z Lizbony zmieniający Traktat o Unii Europejskiej i Traktat ustanawiający Wspólnotę Europejską podpisany w Lizbonie dnia 13 grudnia 2007 r. (Dz.Urz. UE C 306 z 17.12.2007, s. 1-271).

6 J. Carmona, C. Cîrlig, G. Sgueo, UK withdrawal from the European Union. Legal and procedural issues, European Parliamentary Research Service, European Union 2017, s. $4-5$. 
zaś kolejności Unia Europejska na podstawie wytycznych Rady Europejskiej prowadzi negocjacje i zawiera z zainteresowanym państwem umowę określającą warunki jego wystąpienia, przy uwzględnieniu ram dalszych stosunków z Unią. Taka umowa „wystą- pierwotnie upłynąć miał w dniu 29 marca 2019 r., na skutek kolejnych porozumień pomiędzy Radą Europejską a Wielką Brytanią został przesunięty najpierw na dzień 22 maja 2019 r. ${ }^{8}$, następnie na 31 października 2019 r. ${ }^{9}$, wreszcie na 31 stycznia 2020 r. ${ }^{10}$ Tego

\section{Jak pokazała praktyka, niepewność}

\section{co do dalszego członkostwa Wielkiej Brytanii}

w Unii Europejskiej okazała się szczególnie

istotna w kontekście wyborów do Parlamentu

Europejskiego przypadających w roku 2019.

pieniowa" zawierana jest w imieniu UE przez Radę stanowiącą większością kwalifikowaną po uzyskaniu zgody Parlamentu Europejskiego. Postanowienia traktatowe w takim przypadku - co do zasady - przestają mieć zastosowanie w stosunku do państwa „występującego" od dnia wejścia w życie przedmiotowej umowy lub - w razie jej braku - dwa lata po notyfikacji decyzji o wystąpieniu (art. 50 ust 3). Wyjątkiem jest sytuacja, gdy Rada Europejska, działając w porozumieniu z zainteresowanym państwem członkowskim, jednomyślnie podejmie decyzję o przedłużeniu tego okresu. Dodać należy, że wystąpienie państwa ze struktury UE nie oznacza trwałej utraty związku z organizacją. Zgodnie bowiem $\mathrm{z}$ art. 50 ust. 5 TUE państwo, które wystąpiło z UE, może ubiegać się o ponowne członkostwo w zwykłym trybie.

W przypadku Wielkiej Brytanii procedura opuszczenia UE okazała się procesem wyjątkowo trudnym i długotrwałym. Choć notyfikacja decyzji o wystąpieniu nastąpiła w dniu 29 marca 2017 r. , to jednak proces negocjacji umowy wystąpieniowej napotkał na szereg trudności. W ich konsekwencji na wniosek Wielkiej Brytanii termin określony w art. 50 ust. 3 TUE, który

7 Pismo premier Wielkiej Brytanii Theresy May notyfikujące Radzie Europejskiej decyzję o wystąpieniu z UE z dnia 29 marca 2017 r., http://data.consilium.europa.eu/doc/document/XT-20001-2017-INIT/en/pdf (dostęp 9.02.2020). dnia o północy Wielka Brytania opuściła UE. Stała się wówczas państwem trzecim, a co za tym idzie - utraciła prawo do reprezentacji w instytucjach unijnych ${ }^{11}$.

Co jednak wymaga podkreślenia, kilkukrotna prolongata terminu służąca wypracowaniu satysfakcjonujących obie strony warunków brexitu niosła za sobą

8 Przy założeniu, że umowa o wystąpieniu zostałaby zatwierdzona przez Izbę Gmin w następnym tygodniu. W przypadku niedojścia do skutku tych ustaleń Rada Europejska uzgodniła przedłużenie okresu do dnia 12 kwietnia 2019 r. i wskazała, że oczekuje, iż przed dniem 12 kwietnia 2019 r. Zjednoczone Królestwo określi dalsze działania; zob. Decyzja Rady Europejskiej (UE) 2019/476 przyjęta w porozumieniu ze Zjednoczonym Królestwem z dnia 22 marca 2019 r. przedłużająca okres, o którym mowa w art. 50 ust. 3 TUE (Dz. Urz. UE L 80I z 22.3.2019, s. 1-2).

9 Decyzja Rady Europejskiej (UE) 2019/584 przyjęta w porozumieniu ze Zjednoczonym Królestwem z dnia 11 kwietnia 2019 r. przedłużająca okres, o którym mowa w art. 50 ust. 3 TUE (Dz.Urz. UE L 101 z 11.4.2019, s. 1-3).

10 Decyzja Rady Europejskiej (UE) 2019/1810 przyjęta w porozumieniu ze Zjednoczonym Królestwem z dnia 29 października 2019 r. przedłużająca okres, o którym mowa w art. 50 ust. 3 TUE (Dz.Urz. UE L 278I z 30.10.2019, s. 1-3).

11 Brexit: Council adopts decision to conclude the withdrawal agreement, https://www.consilium.europa.eu/en/press/ press-releases/2020/01/30/brexit-council-adopts-decision-to-conclude-the-withdrawal-agreement/ (dostęp 29.03.2020). 
szereg skutków na płaszczyźnie funkcjonowania niemal całej Unii. Opuszczenie UE przez Wielką Brytanię nie było bowiem wyłącznie jej indywidualną sprawą. Należy mieć na uwadze, że Unia funkcjonuje jako organizm będący w istocie systemem naczyń połączonych. Jak pokazała praktyka, niepewność co do dalszego członkostwa Wielkiej Brytanii okazała się szczególnie istotna w kontekście wyborów do Parlamentu Europejskiego przypadających w terminie 23-26 maja 2019 r. Celem niniejszego artykułu jest analiza wpływu wystąpienia przez Wielką Brytanię z UE na przygotowanie, przebieg oraz wyniki wyborów do PE. Jest bowiem oczywiste, że zarówno przygotowanie, jak i przebieg tych wyborów musiały przebiegać w warunkach niepewności co do skuteczności brexitu, który na tamten moment był przecież zdarzeniem przyszłym. Proces ten $-\mathrm{z}$ uwagi na interesujące implikacje na gruncie polskiego prawa wyborczego - zostanie przedstawiony w kontekście organizacji i ustalenia wyników wyborów przeprowadzonych w Polsce.

\section{Brexit a zasady podziału mandatów $w$ PE w kadencji 2019-2024 pomiędzy państwa członkowskie}

Parlament Europejski w systemie instytucjonalnym UE charakteryzuje się szczególnym charakterem. Jego odmienność wynika bowiem z faktu, iż jako jedyna instytucja UE pochodzi z powszechnych i bezpośrednich wyborów ${ }^{12}$. Oznacza to, iż przypisano mu szczególny status, jako gremium o charakterze przedstawicielskim, a zatem legitymowanym bezpośrednio przez obywateli państw członkowskich UE ${ }^{13}$. Rozwią-

12 Pierwsze powszechne i bezpośrednie wybory do PE odbyły się w czerwcu $1979 \mathrm{r}$.

13 J. Maliszewska-Nienartowicz, System instytucjonalny i prawny Unii Europejskiej, Toruń 2010, s. 80. Na marginesie można dodać, że innym przejawem zwiększania demokratycznej legitymizacji instytucji UE jest przyjęcie procedury powoływania Przewodniczącego Komisji Europejskiej w formule tzw. Spitzenkandidat, polegającej na mianowaniu kandydatów przez poszczególne europejskie partie polityczne, por. K. Niklewicz, Sposób na wyborcę, Instytut Obywatelski, „Analiza” 2014, nr 5, s. 6 i n. oraz rezolucja Parlamentu Europejskiego z dnia 22 listopada 2012 r. w sprawie wyborów do Parlamentu Europejskiego w 2014 r., https://www.europarl.europa.eu/sides/getDoc.do?pubRef=-// zanie to koresponduje z sukcesywnym zwiększaniem kompetencji tej instytucji, którego zwieńczeniem są regulacje przyjęte $\mathrm{w}$ Traktacie $\mathrm{z}$ Lizbony ${ }^{14}$.

Podstawowe, wspólne wszystkim państwom członkowskim zasady wyboru przedstawicieli obywateli UE do PE określone zostały w art. 14 TUE oraz w akcie dotyczącym wyborów członków Parlamentu Europejskiego w powszechnych wyborach bezpośrednich, załączonym do decyzji Rady 76/787/EWWiS, EWG, Euratom z dnia 20 września 1976 r. ${ }^{15}$ (dalej: akt z $1976 \mathrm{r}$.). W pozostałym zakresie to na poszczególnych państwach ciąży obowiązek doprecyzowania przepisów regulujących procedurę wyboru na poziomie krajowym. Z punktu widzenia niniejszego opracowania za szczególnie istotną uznać należy regulację zawartą w art. 14 TUE. Zgodnie ze wskazanym przepisem w skład PE wchodzą przedstawiciele obywateli Unii w liczbie nieprzekraczającej 751, wliczając przewodniczącego, zaś reprezentacja obywateli ma charakter degresywnie proporcjonalny, z minimalnym progiem sześciu parlamentarzystów. Oznacza to, iż liczba mandatów przypadających każdemu państwu członkowskiemu jest zależna od liczby mieszkańców tego państwa, przy zastrzeżeniu, że przedstawiciel z państwa członkowskiego o większej liczbie ludności reprezentuje większą liczbę obywateli niż przedstawiciel z państwa o mniejszej liczbie ludności ${ }^{16}$. Zasada ta jest przejawem koniecznej racjonalizacji sposobu podziału mandatów, zważywszy na duże zróżnicowanie ludnościowe poszczególnych państw członkowskich UE. Traktat zastrzega także, iż minimalna liczba posłów wybranych w danym państwie wynosi sześciu, zaś największa - dziewięćdziesięciu sześciu przedstawicieli. Zgodnie $\mathrm{z}$ art. 14 ust. $2 \mathrm{TUE}$ konkretny podział mandatów pomiędzy państwa

$\mathrm{EP} / / \mathrm{TEXT}+\mathrm{TA}+\mathrm{P} 7-\mathrm{TA}-2012-0462+0+\mathrm{DOC}+\mathrm{XML}+\mathrm{V} 0 / / \mathrm{PL}$ (dostęp 10.02.2020).

14 J. Maliszewska-Nienartowicz, System instytucjonalny i prawny..., s. 78-79.

15 Akt dotyczący wyborów członków Parlamentu Europejskiego w powszechnych wyborach bezpośrednich, załączony do decyzji Rady 76/787/EWWiS, EWG, Euratom z dnia 20 września 1976 r. (Dz.Urz. L 278 z 8.10.1976, s. 5).

16 Zob. Decyzja Rady Europejskiej (UE) 2018/937 z dnia 28 czerwca 2018 r. ustanawiająca skład Parlamentu Europejskiego (Dz.Urz. UE L 165 I z 2.7.2018, s. 1-3), art. 1. 
członkowskie powinien zostać dokonany na mocy decyzji Rady Europejskiej przyjętej z inicjatywy i po uzyskaniu zgody PE. W odniesieniu do wyborów do PE, które odbyły się w dniach 23-26 maja 2019 r., decyzja taka wydana została już 28 czerwca 2018 r. ${ }^{17}$ Co jed- tania nadal była członkiem UE, rozdział mandatów pomiędzy państwa dokonany zostanie w oparciu o art. 3 decyzji Rady Europejskiej z 2013 r., a zatem w sposób tożsamy z alokacją mandatów, która miała miejsce podczas wyborów w 2014 r. Podział taki z kolei

\section{Sama notyfikacja decyzji o wystąpieniu z UE} nie konstytuowała sui generis stanu przejściowego, jeśli chodzi o prawa i obowiązki członka UE, a Wielka Brytania na równi z innymi państwami musiała mieć prawo do zapewnienia jej obywatelom wpływu na obsadę personalną Parlamentu Europejskiego.

nak należy podkreślić, Rada Europejska, wykonując zobowiązanie wynikające $\mathrm{z}$ art. 14 ust. 2 TUE, z uwagi na trwający wówczas proces negocjacji pomiędzy UE a Wielką Brytanią w zakresie wystąpienia tego państwa z UE, musiała podjąć konkretne rozstrzygnięcia, działając w niepewności zarówno co do ich efektu, jak i potencjalnego terminu, w którym faktyczne opuszczenie Unii mogłoby nastąpić. W konsekwencji w art. 3 ust. 1 przywołanej decyzji, opierając się na przewidywanym terminie granicznym wynikającym z art. 50 TUE, Rada Europejska dokonała podziału mandatów, zasadniczo nie uwzględniając w nim udziału Wielkiej Brytanii ${ }^{18}$. Jednocześnie, mając na uwadze występującą wówczas niepewność co do losów negocjacji brexitowych, w ust. 2 przytoczonego artykułu poczyniła zastrzeżenie, że w przypadku gdyby na początku kadencji 2019-2024 Wielka Bry-

17 Tamże.

18 Rozwiązanie oparto zatem na przypuszczeniu, że wystąpienie Wielkiej Brytanii z UE nastąpi zgodnie z art. 50 TUE na skutek zawarcia umowy bądź po upływie dwóch lat od momentu notyfikacji Radzie Europejskiej decyzji o wystąpieniu, a zatem jeszcze przed wyborami do PE, w dniu 29 marca 2019 r. miał utrzymać się do czasu, gdy wystąpienie Wielkiej Brytanii z Unii stanie się prawnie skuteczne. Jednocześnie wskazano, że w przypadku zaktualizowania się brexitu, przedstawiciele „zawieszeni” obejmą mandat „w tym samym czasie”. Taki stan rzeczy wynikał z faktu, że sama notyfikacja decyzji o wystąpieniu z UE nie konstytuowała sui generis stanu przejściowego, jeśli chodzi o prawa i obowiązki członka UE, a Wielka Brytania na równi z innymi państwami musiała mieć prawo do zapewnienia jej obywatelom wpływu na obsadę personalną omawianego organu przedstawicielskiego Unii.

Do momentu wyborów do Parlamentu Europejskiego w 2019 r. procedura wystąpienia Wielkiej Brytanii z UE nie została sfinalizowana. Rada Europejska, dostrzegając duże prawdopodobieństwo takiego biegu wydarzeń, już w decyzji z dnia 22 marca 2019 r., uzgadniając przedłużony termin brexitu na dzień 22 maja 2019 r., wskazała: „Jeżeli Zjednoczone Królestwo nadal będzie państwem członkowskim w dniach 23-26 maja 2019 r., będzie miało obowiązek przeprowadzenia wyborów do Parlamentu Europejskiego zgodnie z prawem Unii". Podobnie niepomyślne prognozy dotyczące porozumienia na linii Wielka Brytania - UE pojawiły się w związku z kolejnym wnioskiem Zjed- 
noczonego Królestwa o przesunięcie terminu wynikającego $\mathrm{z}$ art. 50 TUE. Skutkował on wydaniem przez Radę Europejską kolejnej decyzji - z dnia 11 kwietnia 2019 r. Poza prolongatą omawianego terminu na dzień nie późniejszy niż 31 października 2019 r. Rada ponownie podkreśliła wówczas, że dalsze członkostwo Zjednoczonego Królestwa w Unii w dniach 23-26 maja 2019 r., przy jednoczesnym braku ratyfikacji umowy o wystąpieniu do dnia 22 maja 2019 r.,
Europejska zobowiązała Wielką Brytanię do działania w sposób konstruktywny i odpowiedzialny przez cały okres przedłużenia, z poszanowaniem „obowiązku lojalnej współpracy”. Podkreśliła także, iż państwo to w aktualnej sytuacji „musi ułatwiać realizację zadań Unii i powstrzymywać się od wszelkich działań, które mogłyby zaszkodzić osiągnięciu celów Unii, w szczególności podczas uczestnictwa w procesach decyzyjnych ${ }^{19 ”}$.

\section{Doszło do swoistego paradoksu: stojąca u progu} wyjścia z UE Wielka Brytania dokonała wyboru swoich przedstawicieli do PE jako jedno z pierwszych państw członkowskich UE.

będzie związane $\mathrm{z}$ obowiązkiem przeprowadzenia przez nie wyborów do PE zgodnie z prawem Unii. Co istotne, Rada Europejska dodatkowo wyraźnie zapowiedziała, że gdyby wybory w Wielkiej Brytanii nie zostały przeprowadzone, przedłużenie wygaśnie ex lege z dniem 31 maja 2019 r. Takie zastrzeżenie miało służyć zagwarantowaniu, że Wielka Brytania, pomimo pesymistycznego nastawienia wobec konieczności organizacji i przeprowadzenia wyborów, które w dalszej perspektywie mogłyby nie mieć dla niej znaczenia, respektować będzie postanowienia traktatowe. Okoliczność nieprzeprowadzenia wyborów mogłaby bowiem nieść za sobą poważne konsekwencje natury prawnej, zarówno jeśli chodzi o funkcjonowanie PE, jak i w odniesieniu do samego mechanizmu przydzielenia przysługujących po Wielkiej Brytanii (w przypadku brexitu) mandatów. Nie byłoby bowiem możliwe zastosowanie art. 3 ust. 1 decyzji Rady Europejskiej (UE) 2018/937 z dnia 28 czerwca 2018 r., a zatem dokonanie wyboru przedstawicieli poszczególnych państw w liczbie „zwiększonej”, skoro w art. 3 ust. 2 wyraźnie zastrzeżono, że członkostwo Zjednoczonego Królestwa w UE na początku kadencji 2019-2024 implikuje konieczność stosowania dotychczasowego podziału mandatów. Dlatego też Rada
W konsekwencji układ zdarzeń wynikający z obowiązujących przepisów okazał się dość nietypowy. Wielka Brytania, choć bez wątpienia sceptycznie nastawiona do dalszego członkostwa w Unii, jako wciąż jej pełnoprawny członek musiała przeprowadzić głosowanie w wyborach do PE. Biorąc pod uwagę przepisy wewnętrzne, głosowanie to musiało zostać zarządzone na czwartek 23 czerwca 2019 r., a zatem w pierwszy możliwy dzień okresu wyborczego statuowanego przez art. 10 ust. 1 aktu z 1976 r. W konsekwencji doszło do swoistego paradoksu, że to właśnie stojąca u progu wyjścia z UE Wielka Brytania dokonała wyboru swoich przedstawicieli do PE jako jedno z pierwszych państw członkowskich UE. Oznaczało to jednocześnie, że pierwotny podział mandatów po wyborach musiał nastąpić według zasady określonej w art. 3 ust. 2 decyzji Rady Europejskiej (UE) 2018/937, a zatem analogicznie do podziału dokonanego po wyborach w $2014 \mathrm{r}$. $\mathrm{Na}$ marginesie warto odnotować, że inaczej stało się w odniesieniu do procedury powołania Komisji Europejskiej. W tym zakresie, pomimo ciążącego

19 Decyzja Rady Europejskiej (UE) 2019/584, cyt. wyżej (przyp. 9). 
na Wielkiej Brytanii obowiązku, państwo to nie wskazało swojego kandydata ${ }^{20}$.

Na podsumowanie tej części rozważań wskazać należy, że w związku z opuszczeniem UE przez Zjednoczone Królestwo nastąpiła zmiana składu PE. Zgodnie z brzmieniem decyzji Rady Europejskiej (UE) 2018/937 z dnia 28 czerwca 2018 r. w PE od 1 lutego 2020 r. zasiada tylko 705 posłów, co oznacza, że jego skład uległ pomniejszeniu - z dotychczasowych 751 posłów. Spośród siedemdziesięciu trzech mandatów przypadających wcześniej Zjednoczonemu Królestwu rozdzielonych pomiędzy państwa członkowskie zostało dwadzieścia siedem, pozostałe zaś czterdzieści
3. Decyzja Rady Europejskiej (UE) 2018/937 z dnia 28 czerwca 2018 r. ustanawiająca skład PE a regulacje polskiego kodeksu wyborczego

Jak wspomniano wcześniej, długo utrzymująca się niepewna sytuacja Wielkiej Brytanii w UE oraz trudny do określenia moment ostatecznego opuszczenia przez nią struktur unijnych nie oddziaływały tylko na bezpośrednie stosunki na linii Zjednoczone Królestwo - Unia Europejska. Z uwagi na sieć zależności pomiędzy wszystkimi ogniwami UE daleko idące konsekwencje dotknęły także instytucje $\mathrm{UE}^{22}$ oraz państwa członkowskie.

\section{Fakt wydania przez Radę Europejską decyzji}

ustanawiającej skład PE w kadencji 2019-2024,

w którym to dokumencie przewidziano różne

warianty rozdziału mandatów w zależności od układu

wydarzeń, implikował konieczność rozważenia,

a w pewnym zakresie nawet dostosowania do dość dynamicznej sytuacji - regulacji krajowych.

sześć mandatów zostało utrzymanych „w rezerwie”, na wypadek rozszerzeń UE w przyszłości ${ }^{21}$. Odnotowania wymaga także, że wszystkie dwadzieścia siedem mandatów zostało objętych przez przedstawicieli obywateli UE wybranych w głosowaniu przeprowadzonym w dniach 23-26 maja 2019 r.

20 Zob. decyzja Rady Europejskiej (UE) 2019/1989 z dnia 28 listopada 2019 r. w sprawie mianowania Komisji Europejskiej (Dz.Urz. UE L 308 z 29.11.2019, s. 100-102), motywy 7-9 preambuły.

21 Zmiany w Parlamencie Europejskim po Brexicie (nota informacyjna), https://www.europarl.europa.eu/news/pl/ press-room/20200129BKG71304/zmiany-w-parlamencie-europejskim-po-brexicie (dostęp 09.05.2020).
Fakt wydania przez Radę Europejską decyzji ustanawiającej skład PE w kadencji 2019-2024, w którym to dokumencie przewidziano różne warianty rozdziału mandatów w zależności od układu wydarzeń, implikował konieczność rozważenia, a w pewnym zakresie nawet dostosowania do dość dynamicznej sytuacji - regulacji krajowych. W przypadku Polski kwestie problematyczne ujawniły się w co najmniej trzech obszarach. Pierwszym z nich było właściwe

22 Jako kwestia problematyczna jawił się m.in. obowiązek wyznaczenia brytyjskiego komisarza do składu Komisji Europejskiej, zob. Ursula von der Leyen: Londyn musi zgtosić kandydata na komisarza, jeśli Wielka Brytania po 31 października będzie w UE, „Rzeczpospolita” z dnia 24 października 2019 r. 
zredagowanie aktu o zarządzeniu wyborów, w którym zgodnie $\mathrm{z}$ art. $332 \$ 2$ k.w. ${ }^{23}$ Prezydent RP jako organ zarządzający winien wskazać m.in. liczbę posłów do PE wybieranych w Rzeczypospolitej Polskiej. Po drugie, z uwagi na konieczność uwzględnienia wyboru „zwiększonej” liczby przedstawicieli, niezbędnym okazało się uregulowanie trybu wskazania dodatkowego, 52. przedstawiciela, który w przypadku dalszego członkostwa Zjednoczonego Królestwa w UE na początku kadencji 2019-2014, nie mógłby objąć mandatu. Wreszcie jako problem istotny traktować należało kwestię statusu prawnego wspomnianego posła oczekującego na objęcie mandatu, w tym w kontekście przepisów o niepołączalności funkcji i stanowisk.

\subsection{Postanowienie Prezydenta RP o zarządzeniu wyborów do PE}

Odnosząc się do pierwszej ze wspomnianych kwestii, w postanowieniu Prezydenta RP z dnia 25 lutego 2019 r. wskazano, że „w Rzeczypospolitej Polskiej wybiera się 52 posłów do Parlamentu Europejskiego" ${ }^{24}$. Taka redakcja postanowienia w zakresie, $w$ jakim określała liczbę wybieranych przedstawicieli, wydawała się jedynym z możliwych rozwiązań wobec brzmienia art. 3 ust. 1 decyzji Rady Europejskiej z dnia 28 czerwca 2018 r. Biorąc pod uwagę fakt, że w treści decyzji posłużono się pojęciem „liczba przedstawicieli wybieranych do PE”, ustalając ją w przypadku Polski na 52, a także fakt, że art. $332 \$ 2$ k.w. zobowiązywał Prezydenta RP do wskazania liczby posłów „wybieranych w Rzeczypospolitej Polskiej", Prezydent nie mógł wskazać liczby 51 posłów. Ta bowiem, biorąc pod uwagę art. 3 ust. 2 rzeczonej decyzji, wskazywała wyłącznie na liczbę obejmujących funkcje przedstawicieli RP w razie gdyby Wielka Brytania nadal była państwem członkowskim UE na początku kadencji parlamentarnej 2019-2024. Czym innym zatem w rozumieniu decyzji Rady Europejskiej z dnia 28 czerwca 2018 r. była „liczba przedstawicieli wybieranych do PE”, a czym innym „liczba przedstawicieli obejmu-

23 Ustawa z dnia 5 stycznia 2011 r. - Kodeks wyborczy (tekst jedn. Dz.U. z 2018 r., poz. 684 z późn. zm.).

24 Postanowienie Prezydenta Rzeczypospolitej Polskiej z dnia 25 lutego 2019 r. w sprawie zarządzenia wyborów posłów do Parlamentu Europejskiego (Dz.U. z 2019 r., poz. 365). jących funkcje z początkiem kadencji”. Oczywiście należy mieć na uwadze, że gdyby Wielka Brytania sfinalizowała procedurę brexitu przed dniem głosowania, liczby te byłyby tożsame (52). Tak się jednak nie stało, wobec czego jeden z wybranych w Polsce przedstawicieli z początkiem kadencji mandatu nie objął. Na marginesie warto też wskazać, że w decyzji Rady Europejskiej z dnia 28 czerwca 2018 r. mowa jest o liczbie „przedstawicieli” wybieranych do PE. Tym samym $\mathrm{w}$ akcie tym nie posłużono się wprost pojęciem "posłów do PE”. Takie rozwiązanie w kontekście analizowanego problemu umożliwiało większą elastyczność $\mathrm{w}$ interpretacji przepisu, a tym samym w przypadku wyboru większej liczby przedstawicieli w poszczególnych państwach członkowskich, niż liczba faktycznie obejmujących mandat, nie implikowało obowiązku bezwzględnego traktowania każdego z wybranych jako osoby posiadającej status „posła” ze wszelkimi tego konsekwencjami na gruncie prawa krajowego. Jednakże w kontekście polskiego prawa wyborczego zabieg ten niewiele zmieniał. Polski kodeks wyborczy pojęcia „wybranego przedstawiciela” bowiem nie zna, określając każdą osobę wybraną w wyborach mianem posła do $\mathrm{PE}^{25}$.

\subsection{Tryb wskazania 52. posła do PE - oczekujacego na objęcie mandatu}

Procedura, w której wybierana liczba kandydatów może nie być równa liczbie przedstawicieli obejmujących mandat, wymuszona przez sytuację Wielkiej Brytanii oraz treść decyzji Rady Europejskiej z 28 czerwca 2018 r., była dla polskiego kodeksu wyborczego rozwiązaniem całkowicie ekstraordynaryjnym. $Z$ uwagi jednak na fakt związania Polski prawem UE nie ulega wątpliwości, że w takiej sytuacji konieczne było dostosowanie prawa krajowego do rozwiązań unijnych. W związku z powyższym, w braku stosownych regulacji, prawnego dookreślenia wymagała procedura wskazania 52. posła, który choć wybrany zgodnie z regulacjami kodeksu wyborczego, nie mógł objąć mandatu - do czasu, gdy w gronie członków UE pozostawała Wielka Brytania. Na konieczność tę zwracała uwagę Państwowa Komisja Wyborcza jeszcze przed

25 Por. m.in. brzmienie art. $329 \$ 1$ oraz $\$ 2$ k.w., art. $331 \S 1$ k.w., art. $332 \$ 2$ k.w., art. 361 k.w. 
formalnym zarządzeniem wyborów ${ }^{26}$. Wskazując, że kodeks wyborczy nie określa, który z wybranych przedstawicieli miałby nie objąć mandatu z początkiem kadencji, PKW zasygnalizowała, że w konsekwencji problem ten może znaleźć przełożenie na sytuację wszystkich wybranych posłów, gdyż w konsekwencji żaden $\mathrm{z}$ nich mógłby nie objąć mandatu ${ }^{27}$. Taki stan z kolei niweczyłby sens przeprowadzonych wyborów i uniemożliwiał funkcjonowanie PE.

W związku z powyższym w dniu 4 kwietnia $2019 \mathrm{r}$. przyjęta została specustawa o zasadach ustalenia kolejności obsadzania mandatów posłów do Parlamentu Europejskiego wybieranych w Rzeczypospolitej Pol- obowiązujące przepisy ${ }^{29}$. Jak wskazano w opinii do projektu przedmiotowej ustawy, regulacja tak przyjęta stała się lex specialis wobec mechanizmu alokacji mandatów statuowanego w kodeksie wyborczym ${ }^{30}$, regulowała bowiem sytuację nadzwyczajną, która - co do zasady - nie powinna się powtórzyć. Podkreślenia także wymaga, że przedmiotowa ustawa została przyjęta w czasie trwania tzw. ciszy legislacyjnej, przez którą rozumieć należy okres wyłączenia prawa wyborczego spod dokonywania w nim istotnych zmian z uwagi na bezpośrednią bliskość wyborów ${ }^{31}$. Odnotować tu należy, że zgodnie z orzecznictwem TK zmian w prawie wyborczym posiadających cechę „istotności” nie

\section{Procedura, w której wybierana liczba kandydatów} może nie być równa liczbie przedstawicieli obejmujących mandat, wymuszona przez sytuację Wielkiej Brytanii oraz treść decyzji Rady Europejskiej z 28 czerwca 2018 r., była dla polskiego kodeksu wyborczego rozwiązaniem całkowicie ekstraordynaryjnym.

skiej na kadencję 2019-2024 ${ }^{28}$, która miała rozwiązać zaistniały problem. W istocie był to akt normatywny o charakterze epizodycznym, którego treść nie ingerowała bezpośrednio w brzmienie regulacji kodeksowych. Celem ustawy było natomiast rozwiązanie konkretnego, jednostkowego problemu prawnego, czego nie sposób było uczynić w oparciu o aktualnie

26 Zob. pismo Przewodniczącego PKW z dnia 13 lutego 2019 r. do Prezydenta RP, Marszałka Sejmu RP, Marszałka Senatu RP oraz Prezesa Rady Ministrów (ZPOW 501-22/19).

27 Tamże.

28 Ustawa z dnia 4 kwietnia 2019 r. o zasadach ustalenia kolejności obsadzania mandatów posłów do Parlamentu Europejskiego wybieranych w Rzeczypospolitej Polskiej na kadencję 2019-2024 (Dz.U. z 2019 r., poz. 708).
29 Warto odnotować, że podobnie postąpiono w roku 2010, przyjmując ustawę z dnia 4 marca 2010 r. o zasadach obsadzenia w kadencji trwającej w latach 2009-2014 dodatkowego mandatu posła do Parlamentu Europejskiego (Dz.U. z 2010 r., nr 56, poz. 337 z późn. zm.).

30 J. Szymanek, Ocena skutków regulacji poselskiego projektu ustawy o zasadach ustalania kolejności obsadzania mandatów posłów do Parlamentu Europejskiego wybieranych $w$ Rzeczypospolitej Polskiej na kadencje 2019-2024 (druk nr 3272), opinia prawna Biura Analiz Sejmowych KS, http:// www.sejm.gov.pl/sejm8.nsf/opinieBAS.xsp?nr=3272 (dostęp 25.02.2020), s. 2.

31 A. Pyrzyńska, Stabilność prawa wyborczego a zasada demokratycznego państwa prawa (w:) Problemy prawa polskiego i obcego w ujęciu historycznym, praktycznym i teoretycznym. Część ósma, red. A. Bielecki, D. Szafrański, T. Gąsior, Warszawa 2017, s. 135. 
można dokonywać w okresie co najmniej sześciu miesięcy poprzedzających wybory, licząc ten termin od pierwszej czynności kalendarza wyborczego ${ }^{32}$. Choć nie ulega wątpliwości, że sposób ustalenia podziału mandatów należy do tej grupy przepisów, to względy obiektywne, przede wszystkim zaś konieczność dosto- noczone Królestwo nadal byłoby członkiem Unii. Trudno jednak nie zauważyć, że na zgoła inny zakres przedmiotowy wskazywał sam tytuł aktu, sugerujący, iż jego przedmiotem jest „ustalenie kolejności obsadzania mandatów posłów do PE wybieranych w Polsce na kadencję 2019-2024". Kolejność ta jed-

\section{Rozwiązanie problemu wskazania 52. posła, będącego de facto posłem oczekującym na objęcie mandatu,} nastąpiło w ustawie z dnia 4 kwietnia 2019 r. za sprawą przyjęcia analogii do art. $368 \$ 6$ k.w.

sowania norm krajowych do unijnych oraz konieczność zapewnienia realizacji podmiotowych praw wyborczych, przemawiały za zasadnością, a co za tym idzie dopuszczalnością przyjęcia wspomnianej, ekstraordynaryjnej regulacji $i^{33}$.

Celem przedmiotowej ustawy było ustalenie sposobu wskazania posła do PE, który nie obejmie mandatu na początku kadencji, w przypadku gdy w związku z przepisami UE liczba posłów do PE wybieranych w Polsce, obejmujących swoje funkcje na początku kadencji, wyniesie 51. Innymi słowy: zadaniem ustawy było określenie mechanizmu wyznaczenia 52. posła "oczekującego" - w sytuacji gdy w momencie rozpoczęcia kadencji Parlamentu Europejskiego Zjed-

32 Wyrok TK z dnia 3 listopada 2006 r., K 31/06, Legalis nr 77572 oraz wyrok TK z dnia 11 lipca 2011 r., K 9/11, Legalis 343106.

33 Ponadto P. Chybalski w swojej opinii do projektu ustawy wskazuje zasadnie na okoliczność, iż dopuszczalność przyjęcia przedmiotowej ustawy, mimo iż dotyczy ona spraw „istotnych”, determinowana jest okolicznościami niezależnymi od działań polskich organów władzy państwowej, zob. P. Chybalski, Opinia prawna w sprawie projektu ustawy o zasadach ustalenia kolejności obsadzania mandatów posłów do Parlamentu Europejskiego wybieranych $w$ Rzeczypospolitej Polskiej na kadencję 2019-2024, http://www.sejm.gov. pl/sejm8.nsf/opinieBAS.xsp?nr=3272 (dostęp 25.02.2020), s. 5. nak jest w sposób kompleksowy unormowana przepisami kodeksu wyborczego, a jej zmiana nie jest ani konieczna, ani tym bardziej w przedstawionych okolicznościach dopuszczalna. W przedmiotowej sprawie niewiadomą pozostawało jedynie dookreślenie sposobu wskazania posła oczekującego, bez modyfikacji kodeksowego mechanizmu dystrybucji mandatów. W tym zakresie zatem sam tytuł ustawy, który ze swej istoty winien określać w sposób ścisły jej zakres przedmiotowy, należy - biorąc pod uwagę zasady techniki prawodawczej - ocenić krytycznie ${ }^{34}$.

Rozwiązanie problemu wskazania 52. posła, będącego de facto posłem oczekującym na objęcie mandatu, nastapiło w ustawie z dnia 4 kwietnia 2019 r. za sprawą przyjęcia analogii do art. $368 \$ 6$ k.w. Reguluje on sytuację objęcia wakującego mandatu przez posła danego komitetu wyborczego z innej jednak listy okręgowej niż ta, z której mandat posła wygasł, w sytuacji braku kandydata z tej listy. Ustawa określa,

34 Odwołać należy się w tym zakresie do $\$ 18$ ust. 1 załącznika do Rozporządzenia Prezesa Rady Ministrów z dnia 20 czerwca 2002 r. w sprawie "Zasad techniki prawodawczej” (tekst jedn. Dz.U. z 2016 r., poz. 283). Zgodnie z tym przepisem „przedmiot ustawy określa się możliwie najzwięźlej, jednakże w sposób adekwatnie informujący o jej treści”. Trudno stwierdzić, by tytuł przedmiotowej ustawy odpowiadał tej dyrektywie. 
iż w pierwszej kolejności PKW, po ustaleniu wyników wyborów w trybie określonym w art. 354-359 k.w., powinna ustalić, któremu komitetowi spośród tych, które uzyskały mandaty, przypada 52. iloraz. Następnie zaś winna ustalić, „który spośród posłów do $\mathrm{PE}$ wybranych $\mathrm{z}$ list tego komitetu wyborczego uzyskał najmniejszą liczbę głosów”. W tym zakresie można zastanawiać się nad poprawnością tej regulacji, w istocie o „wyborze” - jak się wydaje - należałoby bowiem mówić dopiero po finalnym ustaleniu wyników, tym niemniej to właśnie ten poseł zgodnie z brzmieniem ustawy miał być 52. posłem, oczekującym na objęcie mandatu. Takie rozwiązanie in genere uznać należy za słuszne. Z jednej strony stanowi nawiązanie do aktualnie obowiązujących regulacji, $\mathrm{z}$ drugiej zaś opiera się na racjonalnym mechanizmie przypisania ostatniego, 52. mandatu, tej liście, która po rozdysponowaniu „W zwykłym trybie” 51 mandatów otrzymała kolejno największą liczbę głosów, a zarazem temu kandydatowi z list tego komitetu, który w tym trybie był najlepiej legitymowany, lecz znalazł się poza podziałem mandatów. Odnotowania wymaga, że takie właśnie rozwiązanie postulowała też PKW w swoim piśmie skierowanym do Prezydenta RP, Marszałka Sejmu RP, Marszałka Senatu RP oraz Prezesa Rady Ministrów w lutym 2019 r. ${ }^{35}$, a zatem jeszcze przed zarządzeniem wyborów do PE. Fakt ten wskazuje na ważną rolę PKW jako centralnego organu wyborczego, którego zadaniem jest m.in. sygnalizowanie najwyższym organom władzy RP ważnych problemów praktycznych związanych z procedurami wyborczymi.

\subsection{Status posła do PE oczekującego na objęcie mandatu - w świetle polskich regulacji prawnych}

Odnosząc się do problematyki statusu prawnego - w kontekście decyzji Rady Europejskiej (UE) 2018/937 z dnia 28 czerwca z 2018 r. - owego 52. przedstawiciela wybranego w Polsce do PE, w pierwszej kolejności rozstrzygnąć trzeba, czy osobę tę można było określać mianem „posła do PE” bądź - posługując się terminologią TUE i aktu z 1976 r. „członka PE”, czy też w istocie należy w tym przypadku mówić o innym statusie takiej osoby. Jak wspomniano wcześ-

35 Pismo Przewodniczącego PKW z dnia 13 lutego 2019 r., cyt. wyżej (przyp. 26). niej, obowiązujące przepisy wprowadzają w pewnym sensie zamęt terminologiczny. Wynika on przede wszystkim z faktu, iż Rada Europejska w odniesieniu do osób wybranych wyborach w 2019 r. w decyzji posłużyła się określeniem „przedstawicieli wybieranych do Parlamentu Europejskiego". Tym samym, jak się wydaje, organ ten dążył do pozostawienia państwom członkowskim pewnego luzu decyzyjnego w zakresie dookreślenia statusu podmiotów „oczekujących na objęcie mandatu" - na gruncie prawa krajowego.

Zestawiając jednak brzmienie decyzji we wskazanym wyżej zakresie z polskimi regulacjami, wskazać należy, że na gruncie kodeksu wyborczego próżno szukać sui generis instytucji „przedstawiciela wybranego" - jako wyjątkowego podmiotu o jakimś szczególnym statusie. Nie ulega natomiast wątpliwości, że termin ten konsumuje kodeksowe pojęcie posła do PE, a zatem osoby wybranej w takich wyborach. Jeśli chodzi zaś o brzmienie regulacji zawartych w ustawie z dnia 4 kwietnia 2019 r., to ustawodawca zachował spójność z brzmieniem ustawy wyborczej, tytułując potencjalnego 52. reprezentanta Polski w PE wprost mianem „posła do PE, który nie obejmie mandatu na początku kadencji” (art. 1 ustawy z 4 kwietnia). W konsekwencji uznać trzeba, że na gruncie polskich regulacji mówić należy o pośle do PE jako osobie skutecznie wybranej w wyborach zarządzonych na dzień 26 maja 2019 r., która jednak wraz z rozpoczęciem kadencji PE 2019-2024 nie przystąpiła do wykonywania czynności związanych z udzielonym jej przez wyborców pełnomocnictwem. Innymi słowy - to osoba, która uzyskała mandat w wyborach, przy czym jego objęcie zostało odsunięte w czasie i - co bez wątpienia stanowi novum - uzależnione od warunku zawieszającego w postaci opuszczenia UE przez Wielką Brytanię ${ }^{36}$, co nastąpiło o północy 31 stycznia $2020 \mathrm{r}$.

Jeśli chodzi o status 52. posła wybranego w Polsce, to odnoszą się do niego przepisy przytoczonej ustawy

36 Samo rozdzielenie nabycia i objęcia mandatu nie stanowi rozwiązania wyjątkowego w prawie wyborczym. Co do zasady jednak objęcie mandatu jest zależne od czynności w przepisach wprost przewidzianej, np. w postaci złożenia ślubowania; szerzej M. Chmaj, Zagadnienia ogólne (w:) M. Chmaj, W. Skrzydło, System wyborczy w Rzeczypospolitej Polskiej, Warszawa 2008, s. 20. 
z dnia 4 kwietnia 2019 r. Warto jednak odnotować, że w pierwotnej wersji akt ten regulować miał wyłącznie tryb wyłonienia 52. reprezentanta, niemal zupełnie pomijając szczególną pozycję takiej osoby ${ }^{37}$. Ujęcie w przedmiotowej ustawie problematyki statusu posła oczekującego było dopiero konsekwencją wątpliwości zgłaszanych w opiniach przygotowanych do projektu $\mathrm{aktu}^{38}$, a także w dyskusji toczącej się podczas rozpatrywania ustawy w Senacie. To właśnie na skutek poprawki senackiej znalazły się w ustawie art. 6 i $7^{39}$. Zgodnie z tymi przepisami do czasu objęcia mandatu przez 52. posła do PE nie mógł on wykonywać praw i obowiązków z tych mandatem powiązanych. Po drugie zaś do osoby tej nie miały zastosowania przepisy o zakazie łączenia z funkcją posła do PE stanowisk i funkcji ustalonych zgodnie $\mathrm{z}$ art. 7 ust. 3 aktu z 1976 r.

W pierwszym przypadku ustawodawca jasno odniósł się do sfery uprawnień i obowiązków posła „oczekującego", wskazał bowiem, że do czasu objęcia mandatu nie mógł on wykonywać powiązanych z mandatem obowiązków. Poseł ów nie miał zatem prawa np. do udziału w posiedzeniach $\mathrm{PE}$, oddawania głosu w przeprowadzanych głosowaniach, a także do zrzeszenia się w europejskich grupach politycznych. Ustawodawca wskazał także, że poseł ten „nie wykonuje [swoich] praw". Jak się wydaje, w istocie chodziło o niekorzystanie przez niego z praw przysługujących posłom do PE, w tym przywilejów i immunitetów, o których mowa w art. 6 aktu z 1976 r. W tym kontekście zatem uprawnione wydaje się twierdzenie, iż w istocie przedstawiciel ten do czasu skutecznego wystąpienia przez Zjednoczone Królestwo z UE był w pewnym sensie „zawieszony” w korzystaniu z praw i w zakresie

37 Por. poselski projekt ustawy o zasadach ustalenia kolejności obsadzania mandatów posłów do Parlamentu Europejskiego wybieranych w Rzeczypospolitej Polskiej na kadencję 2019-2024 (druk sejmowy 3272), https://www.sejm.gov.pl/ Sejm8.nsf/druk.xsp?nr=3272 (dostęp 21.02.2020).

38 Zob. P. Chybalski, Opinia prawna..., s. 7.

39 Zob. uchwała Senatu RP z dnia 21 marca 2019 r. w sprawie ustawy o zasadach ustalenia kolejności obsadzania mandatów posłów do Parlamentu Europejskiego wybieranych w Rzeczypospolitej Polskiej na kadencję 2019-2024, https:// www.senat.gov.pl/prace/senat/proces-legislacyjny-w-senacie/ ustawy-uchwalone-przez-sejm/ustawy-uchwalone-przez-sejm/ustawa,774.html (dostęp 21.02.2020). wykonywania obowiązków, które wobec członka PE przewiduje prawo unijne.

Odnosząc się do statusu posła do PE, nie sposób pominąć wspomnianego wcześniej art. 6 ustawy z dnia 4 kwietnia 2019 r. Reguluje on bowiem kluczowe zagadnienie niepołączalności funkcji i stanowisk, immanentnie powiązane ze statusem posła do PE. Jak słusznie zauważono podczas prac legislacyjnych, wskazanie posła „zawieszonego”, zwanego także „oczekującym”, generowało konieczność doprecyzowania możliwości piastowania przez niego innych funkcji i stanowisk. Jak się wydaje, celem art. 7 aktu z 1976 r., który statuuje wobec posłów do PE zasadę incompatibilitas, było zapewnienie separacji wykonywania władzy krajowej i na poziomie unijnym, stworzenie właściwych warunków organizacyjnych do wykonywania mandatu ${ }^{40}$, a także zapewnienie minimalnych gwarancji zapobiegających zjawiskom o charakterze korupcyjnym wśród przedstawicieli narodów UE. Przyjęto zatem, że skoro poseł „zawieszony” nie korzysta z praw ani nie wykonuje obowiązków posła do PE, oczekując na objęcie mandatu, nie powinien być objęty zasadą incompatibilitas $\mathrm{w}$ zakresie wynikającym $\mathrm{z}$ art. 7 aktu z 1976 r. W okresie „zawieszenia” osoba taka bowiem nie ma realnych możliwości podjęcia działań, które wywoływałyby potencjalny konflikt interesów. Po drugie zaś, zważywszy na szczególne okoliczności, niewiadomym wówczas było, jak długo ów stan „zawieszenia” posła będzie się utrzymywał, a nawet - czy w ogóle obejmie on mandat. $Z$ tego też względu ograniczenie jego prawa do piastowania innych ważnych funkcji byłoby nieuzasadnione i niecelowe zarazem. Biorąc jednak pod uwagę brzmienie art. 6 ust. 1 i 2 ustawy, należy stwierdzić, że określenie, jaki zakres wyłączenia miał na myśli ustawodawca, nie jest zadaniem prostym. Artykuł 6 ust. 1 ustawy wskazuje bowiem, iż do czasu objęcia przez posła mandatu nie mają do niego zastosowania przepisy o zakazie łączenia $\mathrm{z}$ funkcją posła do PE stanowisk i funkcji ustalonych zgodnie z art. 7 ust. 3 aktu z 1976 r. Przepis ten natomiast wskazuje na możliwość „rozszerzenia przez państwo członkowskie postanowień dotyczących niepołączalności na poziomie krajowym”. Biorąc zatem pod uwagę

40 A. Kisielewicz (w:) Kodeks wyborczy. Komentarz, K.W. Czaplicki i in., Warszawa 2018, s. 695-696. 
literalne i łączne brzmienie art. 6 ust. 1 ustawy oraz art. 7 ust. 3 aktu z 1976 r., stwierdzić należy, że intencją polskiego ustawodawcy - na podstawie tego przepisu było wyłączenie wobec 52. posła ograniczeń w zakazie pełnienia tylko tych funkcji i stanowisk, których nie wymieniono expressis verbis $\mathrm{w}$ przepisach unijnych, a zatem w art. 7 ust. 1 i 2 aktu z 1976 r. Innymi słowy wyłączenie stosowania zasady incompatibilitas wobec posła „oczekującego" na podstawie art. 6 ust. 1 ustawy dotyczyć miało wyłącznie stanowisk wskazanych na poziomie krajowym w art. 334 in fine k.w. Zgodnie z nim poseł do PE nie może zajmować stanowisk lub pełnić funkcji, których stosownie do przepisów Kon- na posła do PE osoba wybrana jako 52. polski reprezentant piastowała mandat posła, senatora, radnego lub organu wykonawczego w gminie, to zachowywała ów mandat w związku ze wskazanymi wyżej szczególnymi okolicznościami.

Na uwagę jednak zasługuje inna okoliczność. Jak słusznie wskazuje Maciej Pach ${ }^{41}$, brzmienie przyjętej regulacji nie rozwiązało wszystkich sytuacji, jakie mogły zaistnieć w odniesieniu do posła „zawieszonego" wybranego w wyborach 26 maja 2019 r. O ile przepisy ustawy epizodycznej wyłączyły zasadę incompatibilitas w zakresie piastowanych przez tę osobę krajowych funkcji pochodzących z wyboru w momencie nabycia

\section{De lege lata objęcie mandatu posła na Sejm} czy senatora $\mathrm{w}$ wyborach przeprowadzonych w Polsce w dniu 13 października 2019 r., a zatem $w$ toku trwania kadencji $\mathrm{PE}$, powinno było

\section{skutkować wygaśnięciem mandatu posła do PE.}

stytucji RP albo ustaw nie można łączyć ze sprawowaniem mandatu posła na Sejm albo senatora. Choć ogólny katalog wyłączeń dotyczący posłów do PE jest zdecydowanie szerszy - art. 333 i 334 k.w. wskazują nadto na zakaz łączenia mandatu posła do PE z mandatem posła na Sejm, senatora oraz członka Rady Ministrów - to brzmienie art. 7 ust. 3 aktu z 1976 r., o którym mowa we wskazanym wcześniej art. 6 ust. 1 ustawy z 4 kwietnia 2019 r., do nich nie odsyła, gdyż ograniczenia te wynikają już z prawa unijnego. Jednocześnie uzupełnieniem wskazanej wyżej regulacji jest art. 6 ust. 2 ustawy z 4 kwietnia 2019 r., zgodnie z którym do posła oczekującego nie stosuje się art. 247 $\$ 1$ pkt 7, art. $279 \$ 1$ pkt 7, art. $383 \$ 1$ pkt 6 i art. 492 $\$ 1$ pkt 5a k.w. Są to przepisy, które wskazują kolejno na utratę mandatu posła na Sejm, senatora, radnego oraz wójta (burmistrza, prezydenta miasta) w związku z wyborem na posła do PE. Przyjęcie takiej regulacji skutkować miało tym, iż o ile w momencie wyboru mandatu europejskiego przez posła „Zawieszonego”, to ustawodawca w sposób szczególny nie potraktował sytuacji, w której poseł ten już po uzyskaniu mandatu posła do PE, lecz wciąż przed jego (niepewnym) objęciem, z sukcesem uczestniczyłby w kolejnych krajowych wyborach powszechnych przeprowadzonych w toku kadencji PE (2019-2024). W konsekwencji przyjąć należy, że de lege lata objęcie mandatu posła na Sejm czy senatora w wyborach przeprowadzonych w Polsce w dniu 13 października 2019 r., a zatem w toku trwania kadencji PE, zgodnie z art. $364 \$ 1$ pkt 3 k.w. powinno było skutkować wygaśnięciem mandatu posła do PE. Wobec braku szczególnego wyłączenia przepis ten przy literalnej wykładni powinien znaleźć zastosowanie również wobec posła „zawieszonego”, pomimo

41 M. Pach, Paradoks Tarczyńskiego - były, choć niebyly poseł do $P E$, http://monitorkonstytucyjny.eu/archiwa/10956 (dostęp 21.02.2020). 
okoliczności, iż faktycznie podmiot ten wciąż swego europejskiego mandatu nie objął.

Kwestia ta okazała się szczególnie istotna w związku z zaistnieniem takiej sytuacji po wyborach do Sejmu w 2019 r. W wyborach do PE z 26 maja 2019 r. polskim posłem oczekującym został Dominik Tarczyński, który jednak - „w okresie zawieszenia” - zdecydował się na udział w krajowych wyborach parlamentarnych i uzyskał mandat poselski. Tego rodzaju układ zdarzeń spowodował, że problem, który początkowo mógł wydawać się teoretyczny, stał się jak najbardziej realny. Pomimo wcześniejszych wątpliwości zgłaszanych w przedmiotowej sprawie Marszałek Sejmu RP dopiero w dniu 1 lutego 2020 r., a zatem po wejściu w życie umowy o wystąpieniu Zjednoczonego Królestwa z UE, uznała za właściwe stwierdzenie wygaśnięcia mandatu poselskiego wspomnianej osoby, powołując się w tym zakresie na „Zaistnienie okoliczności określonej w art. $247 \$ 1$ pkt 7 oraz na art. $249 \$ 1$ k.w. ${ }^{42}$ Rozwiązanie to trudno jednak uznać za właściwe. Aprobata takiego działania oznaczałaby bowiem nic innego, jak uznanie, że D. Tarczyński został wybrany na posła do PE w toku trwania kadencji sejmowej. Tymczasem - jak wiadomo - wybory do PE odbyły się dużo wcześniej, mianowicie 26 maja 2019 r. Wtedy też osoba ta stała się posłem do PE, innymi słowy zdobyła mandat, jednakże go nie objęła. Objęcie to, zgodnie z art. 3 ust. 2 decyzji Rady Europejskiej (UE) 2018/937, teoretycznie mogło nastąpić dopiero z dniem 1 lutego $2020 \mathrm{r}$. W zaistniałym stanie faktycznym trzeba jednak uznać, że mandatem, w odniesieniu do którego należałoby stwierdzić wygaśnięcie, wcale nie był mandat krajowy, lecz właśnie mandat posła do PE. Przesłanka jego wygaszenia zaktualizowała się bowiem już z dniem wybrania D. Tarczyńskiego na posła na Sejm RP, co wynika expressis verbis z art. $364 \$ 1$ pkt 3 k.w. Utratę tego mandatu powinna była stwierdzić $\mathrm{w}$ drodze postanowienia Marszałek Sejmu, wskazując, iż nastąpiło to z dniem wyboru, przez co należy rozumieć dzień ogłoszenia w Dzienniku Ustaw Rzeczypospolitej Polskiej obwieszczenia PKW o wynikach wyborów do Sejmu. Tak się jednak nie stało.

42 Postanowienie Marszałka Sejmu Rzeczypospolitej Polskiej z dnia 1 lutego 2020 r. w sprawie stwierdzenia wygaśnięcia mandatu posła Dominika Tarczyńskiego (M.P. z 2020 r., poz. 162).

\section{Podsumowanie}

W każdym przypadku członkostwo w UE generuje daleko idące konsekwencje zarówno dla zainteresowanego państwa, jak i całej organizacji. Jak pokazała praktyka, oddziaływanie to okazało się szczególnie zauważalne w związku z wystąpieniem $\mathrm{z}$ organizacji przez Wielką Brytanię. Problemy ze sfinalizowaniem brexitu wpłynęły w sposób znaczący nie tylko na sam tryb funkcjonowania instytucji unijnych, ale także na sytuację wewnętrzną państw członkowskich w zakresie dotyczącym wyborów posłów do PE w 2019 r. Konieczność zastosowania wytycznych określonych w decyzji Rady Europejskiej z dnia 28 czerwca 2018 r. spowodowała znaczące komplikacje nie tylko w Wielkiej Brytanii, tak niechętnej przeprowadzeniu wyborów, ale także wpłynęły na konieczność dostosowania przepisów krajowych w państwach, które na mocy tej decyzji otrzymały dodatkowe mandaty zawieszone. Jak pokazał polski przypadek - dotychczasowa regulacja nie była dostosowana do tego rodzaju nadzwyczajnych okoliczności. To zaś skutkowało koniecznością przyjęcia ustawy epizodycznej, z założenia mającej rozwiązać problem wskazania dodatkowego, 52. posła - zawieszonego - oraz doprecyzowania jego szczególnego statusu. W tym zakresie na uwagę zasługuje udana kooperacja pomiędzy polskim centralnym organem wyborczym a ustawodawcą, który niezwłocznie zareagował na zgłoszone wątpliwości PKW. Niestety, jak pokazała praktyka, zbyt szybkie procedowanie nad ustawą oraz nieuwzględnienie poważnych wątpliwości zgłaszanych w toku prac parlamentarnych nie pozwoliły objąć regulacją wszystkich możliwych przypadków, czyniąc ustawę z dnia 4 kwietnia 2019 r. aktem niedoskonałym i nierealizującym zakładanych celów.

\section{Bibliografia}

Carmona J., Cîrlig C., Sgueo G., UK withdrawal from the European Union. Legal and procedural issues, European Parliamentary Research Service, European Union 2017.

Chmaj M., Zagadnienia ogólne (w:) M. Chmaj, W. Skrzydło, System wyborczy w Rzeczypospolitej Polskiej, Warszawa 2008, s. 13-33.

Chybalski P., Opinia prawna w sprawie projektu ustawy o zasadach ustalenia kolejności obsadzania mandatów posłów do Parlamentu Europejskiego wybieranych w Rzeczypospolitej Polskiej na kadencję 2019-2024, http://www.sejm.gov.pl/sejm8. nsf/opinieBAS.xsp?nr=3272 (dostęp 25.02.2020). 
Kisielewicz A. (w:) K.W. Czaplicki i in., Kodeks wyborczy. Komentarz, Warszawa 2018, s. 694-697.

Garapich M.P., Brexit - fakty, mity, liczby. Możliwe konsekwencje wystapienia Wielkiej Brytanii z Unii Europejskiej. Analiza głównych osi debat publicznych, Warszawa 2016.

Kupis K., Swój - obcy - inny. Brexit i jego społeczne konsekwencje, „Polonia Journal” 2017, nr 5-6, s. 73-114.

Maliszewska-Nienartowicz J., System instytucjonalny i prawny Unii Europejskiej, Torun 2010.

Niklewicz K., Sposób na wyborcę, Instytut Obywatelski, „Analiza" 2014, nr 5, s. 1-13.

Pach M., Paradoks Tarczyńskiego - były, choć niebyły poseł do PE, http://monitorkonstytucyjny.eu/archiwa/10956 (dostęp 21.02.2020).

Pyrzyńska A., Stabilność prawa wyborczego a zasada demokratycznego państwa prawa (w:) Problemy prawa polskiego i obcego w ujęciu historycznym, praktycznym i teoretycznym. Część ósma, red. A. Bielecki, D. Szafrański, T. Gąsior, Warszawa 2017, s. 131-142.

Szymanek J., Ocena skutków regulacji poselskiego projektu ustawy o zasadach ustalania kolejności obsadzania mandatów posłów do Parlamentu Europejskiego wybieranych $w$ Rzeczypospolitej Polskiej na kadencję 2019-2024 (druk nr 3272), opinia prawna Biura Analiz Sejmowych KS, http://www.sejm.gov.pl/sejm8. nsf/opinieBAS.xsp?nr=3272 (dostęp 25.02.2020).

Szymczyński T.R., Brexit a wyzwania identyfikacyjne w odniesieniu do procesu integracji europejskiej z perspektywy hermeneutycznej, „Rocznik Integracji Europejskiej” 2016, nr 10, 67-80. Ursula von der Leyen: Londyn musi zgłosić kandydata na komisarza, jeśli Wielka Brytania po 31 października będzie w UE, „Rzeczpospolita” z dnia 24 października 2019 r. 